\title{
Cardol-Derived Organophosphorothioates as Inhibitors of Acetylcholinesterase for Dengue Vector Control
}

\author{
Mayara O. Almeida, ${ }^{a}$ Thayllan T. Bezerra, ${ }^{a}$ Nayane M. A. Lima, ${ }^{a}$ Anderson F. Sousa, ${ }^{b}$ \\ Maria T. S. Trevisan, ${ }^{b}$ Viviane G. P. Ribeiro, ${ }^{c}$ Diego Lomonaco ${ }^{\circledR a}$ and Selma E. Mazzetto ${ }^{\circledR * a}$ \\ ${ }^{a}$ Laboratório de Produtos e Tecnologia em Processos (LPT), Universidade Federal do Ceará, \\ Campus do Pici, 60455-900 Fortaleza-CE, Brazil \\ ${ }^{b}$ Laboratório de Produtos Naturais e Biotecnologia (LPNBio), Universidade Federal do Ceará, \\ Campus do Pici, 60455-900 Fortaleza-CE, Brazil \\ 'Instituto de Ciências Exatas e da Natureza (ICEN), \\ Universidade da Integração Internacional da Lusofonia Afro-Brasileira, \\ 62790-000 Redenção-CE, Brazil
}

\begin{abstract}
Aedes aegypti is the main vector of three neglected tropical diseases: dengue, zika and chikungunya. Dengue is under surveillance by health organizations worldwide due to the risk of epidemics. Since there is no specific treatment for dengue, most studies have focused on preventing the reproduction and/or development of the mosquitoes. We studied the larvicidal activity of five phosphates and phosphorothioates derived from cardol, one of the four main components of cashew nut shell liquid (Anacardium occidentale L.), at different concentrations. The organophosphorothioate derivatives were tested for their in vitro inhibitory potential against acetylcholinesterase (AChE). One compound, Cdl.i-dPS (median lethal concentration $\left(\mathrm{LC}_{50}\right)=0.8 \mathrm{ppm}$ ), was four times more efficient compared to an important commercial larvicide, Temephos $\left(\mathrm{LC}_{50}=3.2 \mathrm{ppm}\right)$, and showed greater $\mathrm{AChE}$ inhibition than its monosubstituted analogue and Temephos.
\end{abstract}

Keywords: cardol, AChE inhibition, Aedes aegypti

\section{Introduction}

The female Aedes aegypti mosquito is the main arbovirus vector responsible for three neglected tropical diseases (NTDs): dengue, chikungunya and zika. These diseases pose a serious public health problem that endangers billions of people, mainly in tropical and subtropical regions. Globally, the number of dengue cases has increased drastically in the last decades, causing alarm about the risk of infection. ${ }^{1,2}$ Climate change and resistance to synthetic pesticides are indicated as the main causes of the high dengue burden in developed and third world countries. There are currently no efficient antiviral drugs or vaccines to combat these diseases, so the main strategy for control focuses on preventing the vector proliferation. ${ }^{3-5}$ This situation has attracted intense investigations of the development of natural pesticides with higher efficiency and lower toxicity. ${ }^{3,6}$

*e-mail: selma@ufc.br
Among the strategies adopted, most chemical insecticides attack adult mosquitoes or their larval stages. ${ }^{5,7}$ The reduction of the mosquito population is easier in immature stages (larva or pupa). ${ }^{8}$ Most soluble pesticides are organophosphates that inhibit the enzyme, causing paralysis and then death of larvae. ${ }^{9}$ But, because of the toxic potential of these synthetic insecticides on humans and the environment, bioinsecticides with specific action on larvae have been proposed as viable alternatives to control arbovirus vectors. ${ }^{5,8,10}$ Among natural bioactive compounds, some essential oils are potential larvicides against Aedes aegypti. ${ }^{8,10,11}$ Tropical plants are a source of bioactive organic compounds with larvicidal properties. Some studies ${ }^{12-14}$ have mentioned cashew nut shell liquid (CNSL), a dark viscous oil rich in phenolic compounds, as a cheap and efficient larvicide.

CNSL (Figure 1) is a natural source of phenolic lipids that contain an alkyl side chain of fifteen carbons (C15), that can be saturated or present mono, di, and tri 
unsaturation without conjugation and cis stereochemistry. Each component of CNSL is obtained as a mixture of all homologues and the chemical composition depends on the extraction method. Natural CNSL is mainly composed of anacardic acid (65\%), along with cardol, cardanol, and 2-methylcardol, which are extracted by solvent or cold pressing. CNSL is also obtained in high quantities as a byproduct of cashew nut industrial processing. ${ }^{13}$ The elevated temperatures employed $\left(>180{ }^{\circ} \mathrm{C}\right)$ lead to the decarboxylation of anacardic acid, resulting in technical CNSL, mainly composed of cardanol (65\%) and cardol $(20 \%){ }^{15,16}$

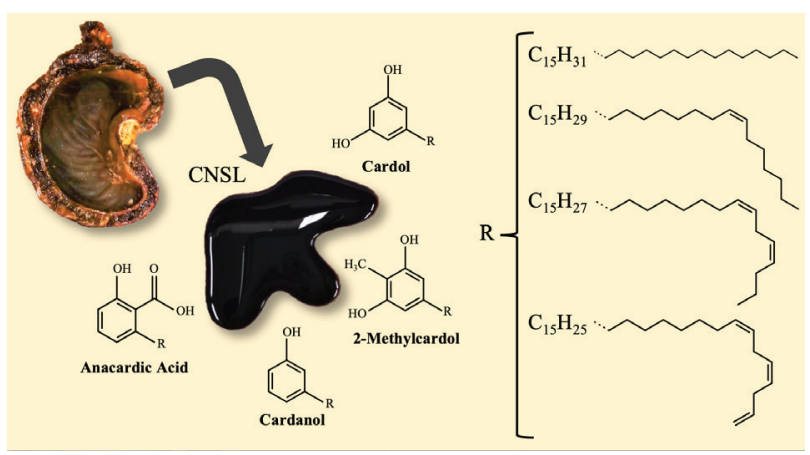

Figure 1. Cashew nut shell liquid (CNSL) and its main constituents.

Previously, we published a study ${ }^{13}$ on CNSL constituents larvicidal activity, and cardol exhibited the best results. Aiming to improve this activity and inspired by the structure of commercial organophosphorus larvicides, in this work we synthesized phosphate and phosphorothioate derivatives of cardol and evaluated their efficiency and mode of action as larvicides and acetylcholinesterase (AChE) inhibitors of Aedes aegypti, for vector control in still water.

\section{Experimental}

Technical CNSL was supplied by Amêndoas do Brasil (Fortaleza, Brazil). Reagents and solvents were supplied by Sigma-Aldrich (Campo Grande, Brazil) and Vetec Química (Campo Grande, Brazil). Cardol and thiophosphorylated compound were analyzed by gas chromatography-mass spectrometry (GC-MS) on a Hewlet-Packard Model 5971 using a (5\%-phenyl)-methylpolysiloxane DB-5 capillary column $(30 \mathrm{~m} \times 0.25 \mathrm{~mm})$ with film thickness $0.1 \mathrm{~mm}$; carrier gas helium, flow rate $1 \mathrm{~mL} \mathrm{~min}^{-1}$ with split mode. The injector temperature and detector temperature were 250 and $200^{\circ} \mathrm{C}$, respectively. Nuclear magnetic resonance (NMR) spectra were recorded on a Bruker Avance DRX$500\left(300 \mathrm{MHz}\right.$ for ${ }^{1} \mathrm{H}$ and $121 \mathrm{MHz}$ for ${ }^{31} \mathrm{P} \mathrm{NMR}$ ) using $\mathrm{CDCl}_{3}$ as solvent for phosphorylated cardol derivatives and acetone- $d_{6}$ for cardol. Column chromatography was run using silica gel 60 (70-230 mesh, Vetec), while thin layer chromatography (TLC) was conducted on precoated silica gel polyester sheets (Kieselgel 60 F254, $0.20 \mathrm{~mm}$, Merck). Compounds were detected by spraying with vanillin-perchloric acid-EtOH solution, followed by heating at $120^{\circ} \mathrm{C}$. Aedes aegypti larvae (Rockefeller strain) were provided by NUVET (Núcleo de Controle de Vetores e Endemias).

Isolation and purification of cardol from CNSL

Cardol (6 g), a viscous dark-brownish oil, was isolated from technical CNSL (45 g), by a methodology previously published, ${ }^{13}$ with few modifications-through silica gel column chromatography eluted with a stepwise gradient of $n$-hexane/ethyl acetate (from 9:1 to 7:3 v/v). The fractions were analyzed through thin layer chromatography (TLC) and the plates were revealed in vanillin solution. The material was rotoeveporated under low pressure to remove the solvents and the viscous oil obtained was characterized by GC-MS and ${ }^{1} \mathrm{H}$ NMR. The GC-MS analysis (Figure S1, Supplementary Information (SI) section) showed a main peak in $37.402 \mathrm{~min}$ corresponding to cardol. The retention time at 37.402 and $37.534 \mathrm{~min}$ were attributed to triene $(66.6 \%)$ and diene cardol $(33.3 \%)$, respectively. Monoene and saturated cardol could not be seen in the analysis due to its low amount in the sample $(<0.1 \%)$. Figures S2 and S3 (SI section) exhibit triene and diene cardol mass spectra, respectively.

\section{Cardol}

${ }^{1} \mathrm{H}$ NMR $\left(300 \mathrm{MHz}\right.$, acetone- $\left.d_{6}\right) \delta 0.84(\mathrm{t}, 3 \mathrm{H}, J 7.2 \mathrm{~Hz}$, $\left.\mathrm{CH}_{3}\right), 1.25\left(\mathrm{~m}, 18 \mathrm{H}, \mathrm{CH}_{2}\right), 1.49\left(\mathrm{~m}, 2 \mathrm{H}, \mathrm{CH}_{2}\right), 1.99$ (m, $\left.2 \mathrm{H}, \mathrm{CH}_{2}\right), 2.36\left(\mathrm{t}, 2 \mathrm{H}, J 7.5 \mathrm{~Hz}, \mathrm{CH}_{2}\right), 2.72\left(\mathrm{~m}, 4 \mathrm{H}, \mathrm{CH}_{2}\right)$, 4.5-5.9 (m, 6H, CH), 6.01 (s, 1H, CH), 6.05 (s, 2H, CH); $m / z, 314\left[\mathrm{M}^{+}\right]$and $m / z, 316\left[\mathrm{M}^{+}\right]$.

Synthesis of cardol di phosphates and phosphorothioates

The monosubstituted and disubstituted organophosphate larvicides were prepared according to the procedure previously described by our group. ${ }^{17-19}$ The synthesis of organophosphate/phosphorothioate larvicides is shown in Scheme 1.

\section{Synthesis of cardol mono phosphates and phosphorothioates}

One mmol of diethyl chlorophosphate or diethyl chlorothiophosphate was added, at room temperature, to a solution of cardol (314 mg; $1 \mathrm{mmol}$ ) and potassium carbonate (138 mg; $1 \mathrm{mmol})$ in acetone $(15 \mathrm{~mL})$. The mixture was magnetically stirred under reflux temperature for $4 \mathrm{~h}$. After 


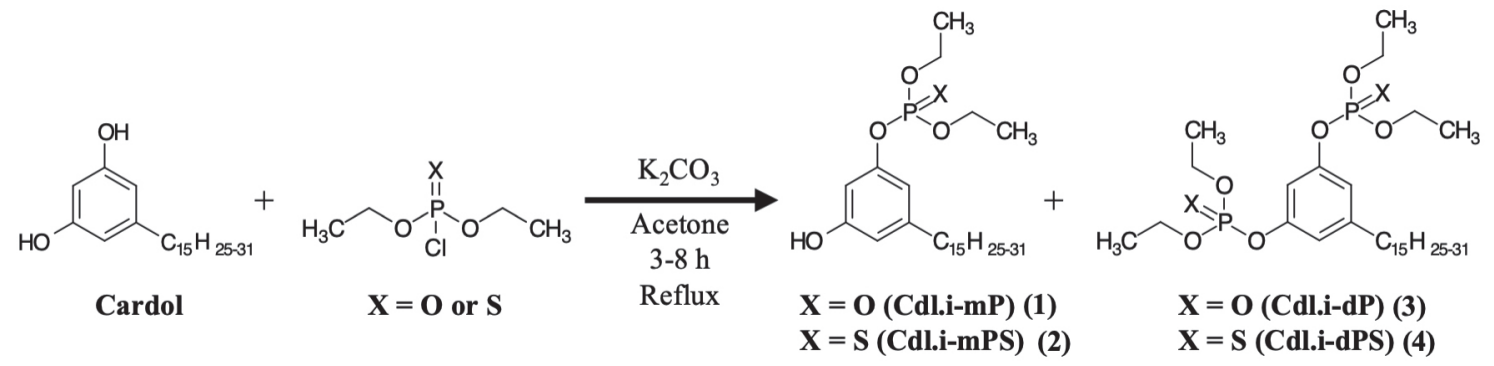

Scheme 1. Diagram of the synthesis of the organophosphate larvicides from cardol.

this period, brine $(40 \mathrm{~mL})$ was added and the resultant solution was extracted with ethyl acetate $(3 \times 40 \mathrm{~mL})$. The removal of the solvent left an oily residue, which was then purified by column chromatography on silica gel (hexane/ ethyl acetate 5:5) to obtain the desired products $\mathbf{1}$ or $\mathbf{2}$, both yellowish oils. The products were characterized by NMR $\left({ }^{1} \mathrm{H}\right.$ and $\left.{ }^{31} \mathrm{P}\right)$ and GC-MS showed the triene homologue as the molecular-ion peak for both compounds, however, there is still the presence of the other homologues.

\section{Compound 1}

$160.14 \mathrm{mg}, 51 \%$; ${ }^{1} \mathrm{H} \mathrm{NMR}\left(300 \mathrm{MHz}, \mathrm{CDCl}_{3}\right) \delta 0.92(\mathrm{t}$, $\left.3 \mathrm{H}, J 7.5 \mathrm{~Hz}, \mathrm{CH}_{3}\right), 1.32\left(\mathrm{~m}, 21 \mathrm{H}, \mathrm{CH}_{2},-\mathrm{P}-\mathrm{O}-\mathrm{CH}_{2}-\mathrm{CH}_{3}\right)$, $1.56\left(\mathrm{~m}, 2 \mathrm{H}, \mathrm{CH}_{2}\right), 2.06\left(\mathrm{~m}, 2 \mathrm{H}, \mathrm{CH}_{2}\right), 2.50(\mathrm{t}, 2 \mathrm{H}, J 7.5 \mathrm{~Hz}$, $\left.\mathrm{CH}_{2}\right), 2.82\left(\mathrm{~m}, 4 \mathrm{H}, \mathrm{CH}_{2}\right), 4.21\left(\mathrm{~m}, 4 \mathrm{H}, \mathrm{P}-\mathrm{O}-\mathrm{CH}_{2}-\mathrm{CH}_{3}\right)$, $5.38(\mathrm{~m}, 6 \mathrm{H}, \mathrm{CH}), 6.46(\mathrm{~s}, 1 \mathrm{H}, \mathrm{CH}), 6.51(\mathrm{~s}, 1 \mathrm{H}, \mathrm{CH})$, $6.79(\mathrm{~s}, 1 \mathrm{H}, \mathrm{CH}) ;{ }^{31} \mathrm{P} \mathrm{NMR}\left(121 \mathrm{MHz}, \mathrm{CDCl}_{3}\right)-6.2 \mathrm{ppm}$; GC-MS $m / z\left[\mathrm{M}^{+}\right]: 450$.

\section{Compound 2}

$194.68 \mathrm{mg}, 62 \%$; ${ }^{1} \mathrm{H} \mathrm{NMR}\left(300 \mathrm{MHz}, \mathrm{CDCl}_{3}\right) \delta 0.92(\mathrm{t}$, $\left.3 \mathrm{H}, J 7.5 \mathrm{~Hz}, \mathrm{CH}_{3}\right), 1.37$ (m, 20H, $\mathrm{CH}_{2},-\mathrm{P}-\mathrm{O}-\mathrm{CH}_{2}-\mathrm{CH}_{3}$ ), $1.58\left(\mathrm{~m}, 2 \mathrm{H}, \mathrm{CH}_{2}\right), 2.05\left(\mathrm{~m}, 2 \mathrm{H}, \mathrm{CH}_{2}\right), 2.53(\mathrm{t}, 2 \mathrm{H}, J 7.5 \mathrm{~Hz}$, $\left.\mathrm{CH}_{2}\right), 2.82\left(\mathrm{~m}, 4 \mathrm{H}, \mathrm{CH}_{2}\right), 4.24\left(\mathrm{~m}, 4 \mathrm{H}, \mathrm{P}-\mathrm{O}-\mathrm{CH}_{2}-\mathrm{CH}_{3}\right)$, 5.02-5.84 (m, 6H, CH), $6.51(\mathrm{~s}, 1 \mathrm{H}, \mathrm{CH}), 6.55(\mathrm{~s}, 1 \mathrm{H}, \mathrm{CH})$; 6.59 (s, $1 \mathrm{H}, \mathrm{CH}) ;{ }^{31} \mathrm{P}$ NMR (121 MHz, $\left.\mathrm{CDCl}_{3}\right) 64.6 \mathrm{ppm}$; GC-MS $m / z\left[\mathrm{M}^{+}\right]: 466$.

\section{Synthesis of cardol di phosphates and phosphorothioates}

The procedure for diphosphorylation of cardol was the same as mentioned above; the only modifications were the stoichiometric ratio and reaction time. Two mmol of diethyl chlorophosphate or diethyl chlorothiophosphate were added, at room temperature, to a solution of cardol (314 mg; $1 \mathrm{mmol}$ ) and potassium carbonate $(276 \mathrm{mg} ; 1 \mathrm{mmol})$ in acetone $(15 \mathrm{~mL})$. The mixture was magnetically stirred under reflux temperature for $6 \mathrm{~h}$. After this period, brine $(40 \mathrm{~mL})$ was added and the resultant solution was extracted with ethyl acetate $(3 \times 40 \mathrm{~mL})$. The removal of the solvent left an oily residue, which was then purified by column chromatography on silica gel (methanol/ethyl acetate 2:8) to afford the desired products $\mathbf{3}$ or $\mathbf{4}$, both yellowish oils. The products were characterized by NMR $\left({ }^{1} \mathrm{H}\right.$ and $\left.{ }^{31} \mathrm{P}\right)$ and GC-MS. Due to higher polarity of $\mathbf{4}$, the triene and diene homologues are retained in the column and the monoene appears as the molecular-ion peak $\left(\mathrm{m} / \mathrm{z}, 622 \mathrm{M}^{+}\right)$.

\section{Compound 3}

$263.76 \mathrm{mg}, 84 \%$; ${ }^{1} \mathrm{H} \mathrm{NMR}\left(300 \mathrm{MHz}, \mathrm{CDCl}_{3}\right) \delta 0.88(\mathrm{t}$, $\left.3 \mathrm{H}, J 7.2 \mathrm{~Hz}, \mathrm{CH}_{3}\right), 1.31\left(\mathrm{~m}, 26 \mathrm{H}, \mathrm{CH}_{2},-\mathrm{P}-\mathrm{O}-\mathrm{CH}_{2}-\mathrm{CH}_{3}\right)$, $1.57\left(\mathrm{~m}, 2 \mathrm{H}, \mathrm{CH}_{2}\right), 2.03\left(\mathrm{~m}, 2 \mathrm{H}, \mathrm{CH}_{2}\right), 2.55(\mathrm{t}, 2 \mathrm{H}, J 7.5 \mathrm{~Hz}$, $\mathrm{CH}_{2}$ ), $2.78\left(\mathrm{~m}, 4 \mathrm{H}, \mathrm{CH}_{2}\right), 4.19$ (m, 8H, P-O- $\mathrm{CH}_{2}-\mathrm{CH}_{3}$ ), 4.94-5.41 (m, 6H, CH), 6.87 (s, 2H, CH), $6.90(\mathrm{~s}, 1 \mathrm{H}$, $\mathrm{CH}) ;{ }^{31} \mathrm{P}$ NMR (121 MHz, $\left.\mathrm{CDCl}_{3}\right)-7.44 \mathrm{ppm}$; GC-MS $m / z\left[\mathrm{M}^{+}\right]: 586$.

\section{Compound $\mathbf{4}$}

$282.60 \mathrm{mg}, 90 \%$; ${ }^{1} \mathrm{H} \mathrm{NMR}\left(300 \mathrm{MHz}, \mathrm{CDCl}_{3}\right) \delta 0.90$ (t, $\left.3 \mathrm{H}, J 6.0 \mathrm{~Hz}, \mathrm{CH}_{3}\right), 1.36\left(\mathrm{~m}, 34 \mathrm{H},-\mathrm{P}-\mathrm{O}-\mathrm{CH}_{2}-\mathrm{CH}_{3}\right), 1.56$ $\left(\mathrm{m}, 2 \mathrm{H}, \mathrm{CH}_{2}\right), 2.04\left(\mathrm{~m}, 2 \mathrm{H}, \mathrm{CH}_{2}\right), 2.80\left(\mathrm{~m}, 4 \mathrm{H}, \mathrm{CH}_{2}\right), 4.22$ (m, 8H, P-O- $\mathrm{CH}_{2}-\mathrm{CH}_{3}$ ), 4.95-5.43 (m, 6H, CH), 6.84 (s, $2 \mathrm{H}, \mathrm{CH}), 6.91(\mathrm{~s}, 1 \mathrm{H}, \mathrm{CH}) ;{ }^{31} \mathrm{P}$ NMR $\left(121 \mathrm{MHz}, \mathrm{CDCl}_{3}\right)$ $62.1 \mathrm{ppm} ; \mathrm{GC}-\mathrm{MS} \mathrm{m} / z\left[\mathrm{M}^{+}\right]: 622$.

\section{Test of larvicidal activity on Aedes aegypti larvae}

The larvicidal activity of monosubstituted ( $\mathbf{1}$ and $\mathbf{2})$ and disubstituted (3 and $\mathbf{4}$ ) organophosphates/phosphorothioates from cardol was tested on Aedes aegypti. Fifty $3^{\text {rd }}$-instar larvae were transferred to a $50-\mathrm{mL}$ beaker containing $19.7 \mathrm{~mL}$ of water. Before inserting the larvicides in the water, they were diluted in $0.3 \mathrm{~mL}$ of dimethyl sulfoxide (DMSO), resulting in concentrations of 4, 10, 20,40, and $100 \mathrm{ppm}$. A control using $1.5 \% \mathrm{DMSO} / \mathrm{H}_{2} \mathrm{O}$ was tested in parallel. Mortality was recorded after $24 \mathrm{~h}$, and the number of dead larvae was used to calculate the median lethal concentration $\left(\mathrm{LC}_{50}\right)$. Both organothiophosphate compounds exhibited promising larvicidal activity (Figure 2). Triplicates were performed for compounds with larvicidal effect. The value of $\mathrm{LC}_{50}$ was determined using the statistical analysis software BioStat 2009. ${ }^{20}$ 


\section{Anticholinesterase activity assay}

This assay was performed according to the method described by Elmann, with adaptations. ${ }^{21,22}$ Aliquots of $15 \mu \mathrm{L}$ of solutions of $\mathbf{2 , 4}$ and commercial larvicide (Temephos), with concentration of $0.45 \mathrm{mg} \mathrm{mL}^{-1}$, were spotted on a TLC plate (DC-Alufolien, Silicagel 60 F254, $0.2 \mathrm{~mm}$ Merck). After complete evaporation of the solvent, a mixture $(1: 1)$ of acetylcholine iodide (ATCl) $1 \mathrm{mmol} \mathrm{L}^{-1}$ was sprayed with the Ellman reagent (5,5'-dithiobis(2-nitrobenzoic acid, DTNB, $1 \mathrm{mmol} \mathrm{L}^{-1}$ ) and left standing for $3 \mathrm{~min}$ for drying. The enzyme acetylcholinesterase (10 $\mathrm{U} \mathrm{mL}^{-1}$ ) was then sprayed. After $10 \mathrm{~min}$, a yellow color appeared as a result of the thio anion formation from the reaction of the enzymatic hydrolysis of the substrate with DTNB. The inhibition of the enzyme leads to the formation of a white halo around the spots where the larvicides were applied. As positive control, an anticholinesterase compound called Eserin was used at $30 \mathrm{mg} \mathrm{mL}^{-1}$.

\section{Results and Discussion}

Synthesis of cardol-derived phosphates and phosphorothioates

Organophosphates are well known for inhibiting acetylcholinesterase (AChE), a crucial enzyme for all living beings, responsible for the passage of impulses between neurons. Neurotoxic compounds like organophosphates hydrolyze acetylcholine, foreclosing the neural excitement, leading to paralysis and then death of the larvae. Temephos, a commercial organophosphorus larvicide, was used as $\mathrm{AChE}$ inhibitor. However, the emergence of resistant strains has led to a search for new biopesticides. ${ }^{23,24}$

Previous works ${ }^{13}$ have used cardol, a natural phenol obtained from CNSL, which presented good larvicidal activity. In order to improve this activity, we inserted phosphate and phosphorothioate groups to cardol's structure, resulting in four compounds, exhibited in Table 1.

\section{Larvicidal bioassay}

Aedes aegypti is a mosquito that breeds in still water, depositing its eggs to hatch, restarting the cycle. The larval stage is an attractive target due to the easy absorption of compounds dissolved in water. ${ }^{25}$

Many commercial pesticides are applied in water bodies, but they can endanger human and animal health. Pesticides derived from natural sources are attractive due to low cytotoxicity. ${ }^{23}$
Phenolic compounds present a wide range of biological properties, including larvicidal activity. ${ }^{26}$ Lomonaco et al. ${ }^{13}$ evaluated the effect of industrial CNSL and its main components (cardanol and cardol) as larvicidal agents against Aedes aegypti. Cardol presented the lowest $\mathrm{LC}_{50}$ values.

Four compounds were synthesized from cardol, two mono and di phosphorylates and two mono and diphosphorothioates. Table 2 shows that the phosphorylation of cardol increases the $\mathrm{LC}_{50}$ to over $100 \mathrm{ppm}$, so it is unsuitable for insecticidal applications. On the other hand, among the organophosphorothioate compounds, we highlight $4\left(\mathrm{LC}_{50}=0.8 \pm 0.3 \mathrm{ppm}\right)$, which is four times more efficient than the commercial larvicide, Temephos $\left(\mathrm{LC}_{50}=3.2 \mathrm{ppm}\right)$.

Phosphate-derivative larvicides exhibit better acetylcholinesterase inhibition, nonetheless, the higher lipophilicity of the parathion $\left(-\mathrm{P}=\mathrm{S}, \log \mathrm{P}_{\mathrm{o} / \mathrm{w}}=3.0\right)$, in relation to the paraoxon $\left(-\mathrm{P}=\mathrm{O}, \log \mathrm{P}_{\mathrm{o} / \mathrm{w}}=1.6\right)$, facilitate the penetration of phosphorothioates into the cell compared to phosphates. ${ }^{27}$ Once inside the cell, the phosphorothioates are readily oxidized to phosphates by the cytochrome $\mathrm{P} 450$ (CYP), responsible for the activation or deactivation of many therapeutic compounds and toxins ${ }^{27,28}$ (Scheme 2). This explain the excellent larvicidal activity of compound 4.

The unsaturation of the side chain of cardol also plays an important role in its larvicidal activity. We synthesized the saturated cardol diphosphorothioates (5), which presented $\mathrm{LC}_{50}=11.7 \mathrm{ppm}$. This value is 14 times higher than that of 4. Kanyaboon et al. ${ }^{25}$ studied the effect of CNSLderived phenolic compounds on dengue virus inhibition. They reported that triene compounds had the best results, followed by dienes, monoenes, and saturated ones. The high degree of unsaturation increases the interaction with transmembrane proteins of the cell membrane, thus, leading to high quantities of larvicide inside the cell.

\section{Morphological alterations}

Figure 2 depicts the morphological alterations observed after larval exposure to technical CNSL, cardol, and 4. After $24 \mathrm{~h}$ of exposure to the biolarvicides, all larvae presented changes in their external structures. Compared to the control group (Figure 2a), technical CNSL (Figure 2b) caused total destruction of larvae's internal structure. Cardol (Figure 2c) exposure caused loss of bristles and shrinking of the exoskeleton. The cardol-derived 4 (Figure 2d) paralyzed the larvae after $1 \mathrm{~h}$ of contact, leading to hardening and contraction of the exoskeleton in $24 \mathrm{~h}$.

The development of new biolarvicides focuses on higher efficiency and less toxicity, thus reducing the 
Table 1. Structure, IUPAC name, and abbreviation of cardol-derived organophosphates and organophosphorothioates

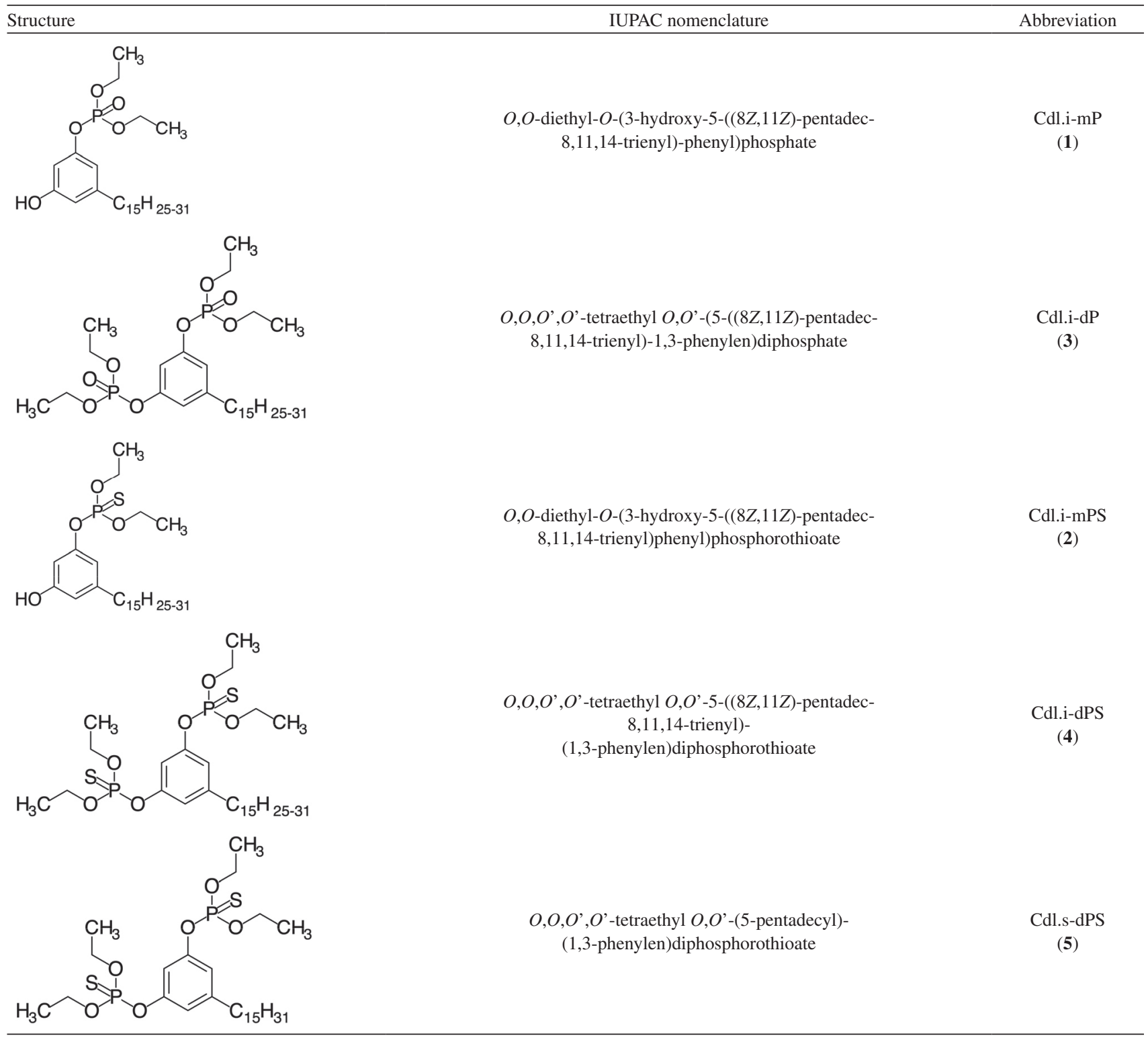

Table 2. $\mathrm{LC}_{50}$ of industrial CNSL, cardanol, cardol and cardol-derived phosphates and phosphorothioates

\begin{tabular}{lc}
\hline Larvicide & $\mathrm{LC}_{50} / \mathrm{ppm}$ \\
\hline Technical CNSL & $51.02 \pm 0.62^{13}$ \\
Cardanol & $28.90 \pm 0.36^{13}$ \\
Cardol & $14.20 \pm 0.62^{13}$ \\
$\mathbf{1}$ & $>100$ \\
$\mathbf{3}$ & $>100$ \\
$\mathbf{2}$ & $9.2 \pm 0.41$ \\
$\mathbf{4}$ & $0.8 \pm 0.30^{\mathrm{a}}$ \\
Cdl.s-dPS (5) & $11.7 \pm 0.35$ \\
Temephos & 3.2 \\
\hline
\end{tabular}

${ }^{a}$ Compound $\mathbf{4}$ is four times more efficient than the commercial larvicide Temephos; $\mathrm{LC}_{50}$ : median lethal concentration; CNSL: cashew nut shell liquid.

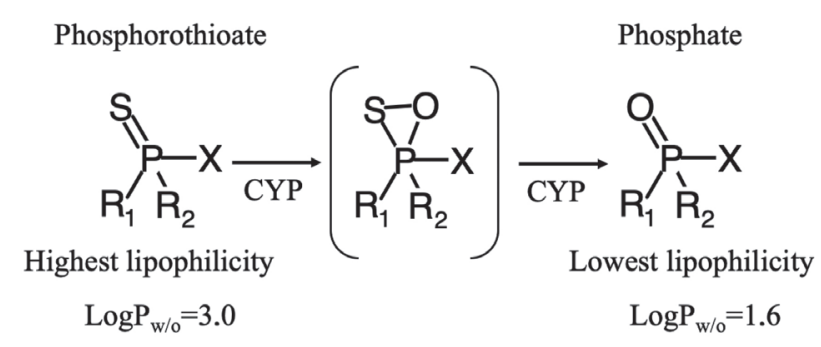

Scheme 2. Enzymatic oxidation mechanism of parathion to paraoxon by cytochrome P450 (CYP).

dependence on expensive and toxic pesticides. Figure 3 shows the larval mortality due to contact with cardolderived organophosphorothioates. A large increase of larval mortality could be observed, even at low concentrations 


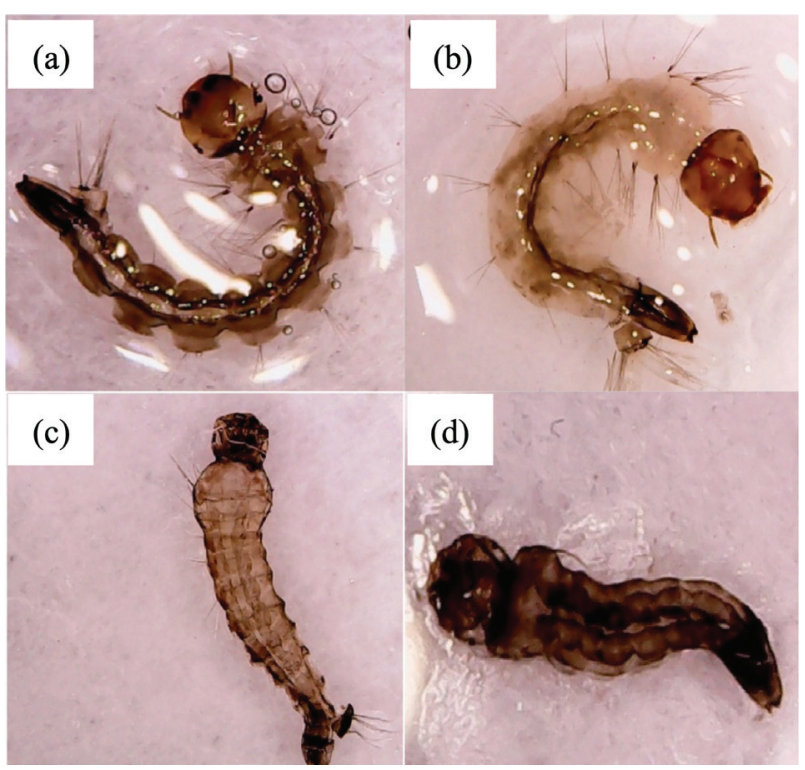

Figure 2. Morphology of Aedes aegypti larvae (a) control; (b) technical CNSL; (c) cardol and (d) 4.

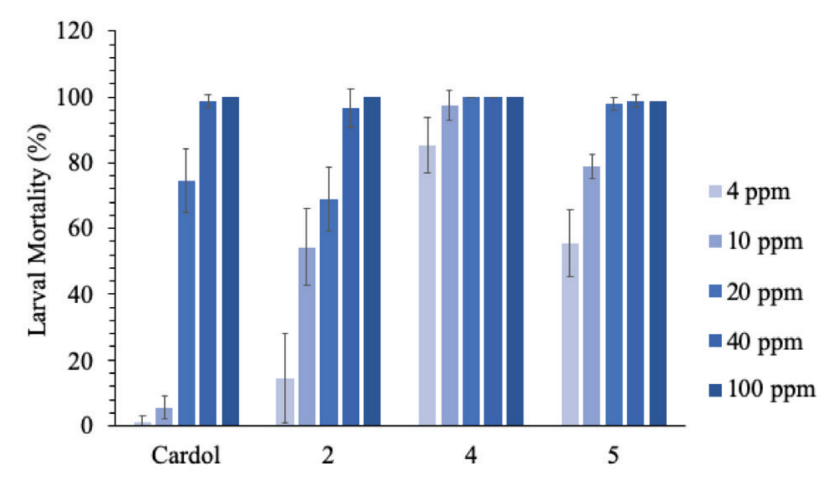

Figure 3. Larval mortality from different concentrations of organophosphorothioates.

for all organothiophosphorylated compounds, especially $\mathbf{4}$, which killed more than $85 \%$ of larvae at $4 \mathrm{ppm}$. The maximum efficiency was observed at $20 \mathrm{ppm}$ for $\mathbf{4}$, followed by 5 at $40 \mathrm{ppm}$, and $\mathbf{2}$ and cardol at $100 \mathrm{ppm}$.

Mode of action

Organophosphorus larvicides inhibit the action of acetylcholinesterase (AChE), an enzyme located primarily in the central nervous system of the entire animal kingdom, including insects, and widely distributed in excitable membranes of nerves and muscles. AChE works at the neural synapse, and once inhibited, it will no longer be able to hydrolyze the neurotransmitter acetylcholine (ACh) into acetate and choline, leading to a series of neurotoxic effects, collapse of the central nervous system and consequently death of the insect. ${ }^{29-31}$

According to Lopez and Fernandez-Bolanos, ${ }^{9}$ the reaction between $\mathrm{ACh}$ and $\mathrm{AChE}$ takes place in three stages, as shown in Scheme 3: (1) formation of the Michaelis complex between the substrate, acetylcholine and AChE; (2) acetylation of the enzyme and formation of choline; and (3) hydrolysis of the acetylated enzyme to yield free enzyme and acetic acid (Scheme 3).

Inhibition of acetylcholinesterase occurs analogously through phosphorylation reaction. A covalent bond is formed between the hydroxyl group from the serine moiety of the enzyme's active site and the organophosphates, resulting in an excess of ACh. The O-P bond formed is highly stable, precluding $\mathrm{ACh}$ from interacting with $\mathrm{AChE}$ (Scheme 4). ${ }^{29}$

\section{AChE inhibition test}

The AChE inhibition test used Sclerin, a drug with anticholinesterase activity, as positive control. Inactivation of the enzyme, which may occur with organophosphates, such as Temephos, leads to the accumulation of acetylcholine, causing a series of neurological effects..$^{30,31}$

The formation of a white halo (Ellman method) around the spots in TLC plates is an indication of AChE inhibition. The diameter of the halos $(\mathrm{cm})$ was compared with the positive pattern of Eserina. As shown in Table 3, 4 had the largest diameter $(1.1 \mathrm{~cm})$, followed by Temephos $(1 \mathrm{~cm})$ and $2(0.9 \mathrm{~cm}) .4$ was the closest to Eserin $(1.5 \mathrm{~cm})$, thus the most efficient. The anticholinesterase activity of technical CNLS derivatives, studied previously by Oliveira et al., ${ }^{32}$ showed that cardol and cardanol presented halo diameters of 1.2 and $0.8 \mathrm{~cm}$, respectively.

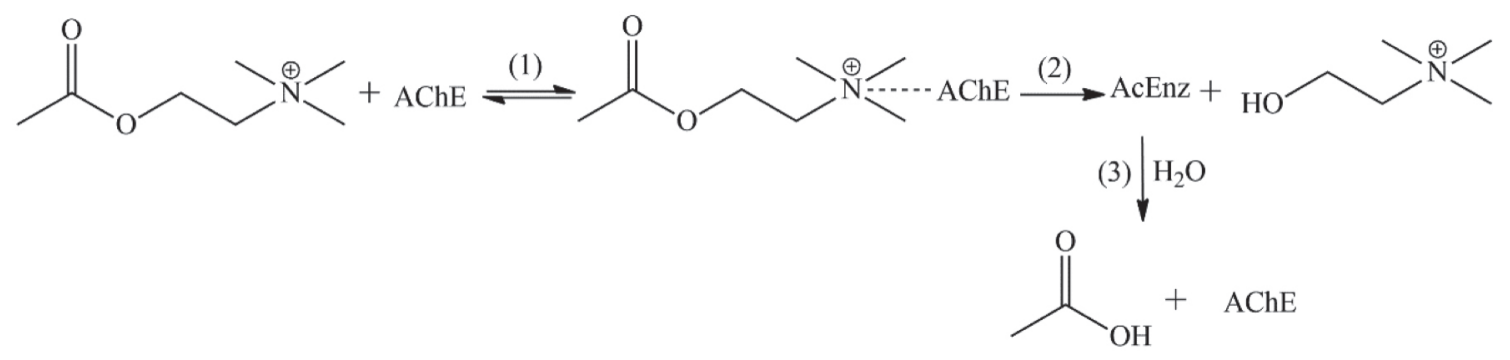


Phosphorylated AChE

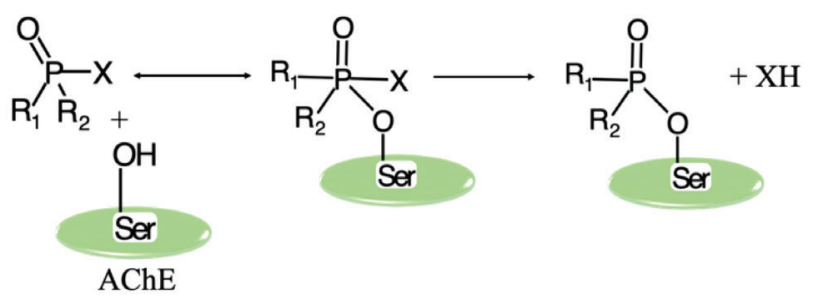

Scheme 4. Acetylcholinesterase (AChE) phosphorylation process.

Table 3. Halo diameter of the larvicides with AChE inhibition

\begin{tabular}{lcc}
\hline AChE inhibitor & Result & Diameter of halos / cm \\
\hline $\mathbf{2}$ & positive & 0.9 \\
$\mathbf{4}$ & positive & $1.1^{\mathrm{a}}$ \\
Temephos & positive & 1.0 \\
Eserina & positive & 1.5 \\
\hline
\end{tabular}

${ }^{\mathrm{a} C o m p o u n d} \mathbf{4}$ had the largest diameter; AChE: acetylcholinesterase.

Despite cardol's highest AChE inhibition in vitro, $\mathbf{4}$ has better interaction with the cell membrane, thus acting faster and more efficiently in vivo. This action is seen in the larvicidal test, where the cardol $\mathrm{LC}_{50}(14.2 \mathrm{ppm})$ is almost 18 times higher than that of $\mathbf{4}(0.8 \mathrm{ppm})$.

\section{Conclusions}

The larvicidal activity of organophosphorothioates against Aedes aegypti can be attributed to inhibition of the enzyme acetylcholinesterase (AChE). Two of the cardolderivatives presented excellent activities, $\mathbf{2}$ and $\mathbf{4}$. We did not test the phosphate derivatives due to high $\mathrm{LC}_{50}$ values, once the presence of the sulfur atom is fundamental for cell membrane permeation and improved larvicidal activity, as demonstrated in Scheme 2. The presence of unsaturations in cardol's side chain increases the efficiency against Aedes aegypti larvae, since the saturated derivative (5) presented a $\mathrm{LC}_{50}$ value 14 times higher than the unsaturated analogue $4\left(\mathrm{LC}_{50}=0.8 \mathrm{ppm}\right)$. Alterations in larvae's external structure were observed after $24 \mathrm{~h}$ of exposure to the biolarvicides. 4 killed more than $85 \%$ of larvae at $4 \mathrm{ppm}$, the lowest concentration tested, and had the highest inhibition of AChE, compared to 2 and the commercial larvicide Temephos, in the Ellman test. Therefore, $\mathbf{4}$ could be considered a promising acetylcholinesterase inhibitor larvicide for dengue vector control.

\section{Supplementary Information}

Supplementary information (mass spectra GC-MS and ${ }^{1} \mathrm{H}$ NMR for cardol, Cdl.i-mP (1), Cdl.i-dP (3),
Cdl.i-mPS (2) and Cdl.i-dPS(4)) is available free of charge at http://jbcs.sbq.org.br as PDF file.

\section{Acknowledgments}

We thank the support from CAPES, CNPq (Brazilian agencies) and FUNCAP (State agency) for the financial support; Amêndoas do Brasil, for providing CNSL; CENAUREMN (Centro Nordestino de Aplicação e Uso da RMN, Fortaleza-CE) for the NMR analyses and; NUVET (Núcleo de Controle de Vetores e Endemias).

\section{References}

1. Hu, W.; Tu, Z. J.; Parasites Vectors 2018, 11, 655.

2. Kannathasan, K.; Senthilkumar, A.; Venkatesalu, V.; Acta Trop. 2011, 120, 115.

3. Daniel, J. F. S.; Silva, A. A.; Nakagawa, D. H.; de Medeiros, L. S.; Carvalho, M. G.; Tavares, L. J.; Abreu, L. M.; RodriguesFilho, E.; J. Braz. Chem. Soc. 2017, 28, 1003.

4. Moreira, A. S. N.; Fernandes, R. O. S.; Lemos, F. J. A.; Braz-Filho, R.; Vieira, I. J. C.; Rev. Bras. Farmacogn. 2016, 26, 530.

5. Rocha, D. K.; Matos, O.; Novo, M. T.; Figueiredo, A. C.; Delgado, M.; Moiteiro, C.; Nat. Prod. Commun. 2015, 10, 677.

6. Kanis, L. B.; Rabelo, B. D.; Moterle, D.; Custódio, K. M.; Oliveira, J. G.; de Lemos, A. B.; Silva, O. S.; Zepon, K. M.; Magnago, R. F.; Prophiro, J. S.; Ind. Crops Prod. 2018, 122, 148.

7. Chansang, A.; Champakaew, D.; Junkum, A.; Jitpakdi, A.; Amornlerdpison, D.; Aldred, A. K.; Riyong, D.; Wannasan, A.; Intirach, J.; Muangmoon, R.; Pitasawat, B.; Parasites Vectors 2018, 11, 417.

8. Feitosa, E. M. A.; Arriaga, A. M. C.; Santiago, G. M. P.; Lemos, T. L. G.; Oliveira, M. C. F.; Vasconcelos, J. N.; Lima, J. Q.; Malcher, G. T.; Nascimento, R. F.; Braz-Filho, R.; J. Braz. Chem. Soc. 2009, 20, 375.

9. Lopez, O.; Fernandez-Bolanos, J. G.; Green Trends in Insect Control; Lopez, O.; Fernandez-Bolanos, J. G., eds.; RSC: Cambridge, 2011.

10. Krzyzaniak, L. M.; Antonelli-Ushirobira, T. M.; Panizzon, G.; Sereia, A. L.; Souza, J. R. P.; Zequi, J. A. C.; Novello, C. R.; Lopes, G. C.; Medeiros, D. C.; Silva, D. B.; Leite-Mello, E. V. S.; Mello, J. C. P.; J. Evidence-Based Complementary Altern. Med. 2017, ID 9602368.

11. Santos, S. R. L.; Melo, M. A.; Cardoso, A. V.; Santos, R. L. C.; Sousa, D. P.; Cavalcanti, S. C. H.; Chemosphere 2011, 84, 150.

12. Laurens, A.; Fourneau, C.; Hocquemiller, R.; Cavé, A.; Bories, C.; Loiseau, P. M.; Phytother. Res. 1997, 11, 145.

13. Lomonaco, D.; Santiago, G. M. P.; Ferreira, Y. S.; Arriaga, A. M. C.; Mazzetto, S. E.; Mele, G.; Vasapollo, G.; Green Chem. 2009, 11, 31 . 
14. Paiva, D. R.; de Lima, D. P.; Avvari, N. P.; Arruda, E. J.; Cabrini, I.; Marques, M. R.; Santos, E. A.; Biaggio, F. C.; Sangi, D. P.; Beatriz, A.; An. Acad. Bras. Cienc. 2017, 89, 373.

15. Mota, J. P. F.; Ribeiro, V. G. P.; da Silva, F. L. F.; Costa Jr., A. E.; Oliveira, D. R.; Kotzebue, L. R. V.; Mele, G.; Lomonaco, D.; Mazzetto, S. E.; Sep. Sci. Technol. 2016, 51, 2473.

16. Mazzetto, S. E.; Lomonaco, D.; Mele, G.; Quim. Nova 2009 , 32,732 .

17. Lomonaco, D.; Cangane, F. Y.; Mazzetto, S. E.; J. Therm. Anal. Calorim. 2011, 104, 1177.

18. Lomonaco, D.; Maia, F. J. N.; Mazzetto, S. E.; J. Therm. Anal. Calorim. 2013, 111, 619.

19. Lomonaco, D.; Maia, F. J. N.; Clemente, C. S.; Mota, J. P. F.; Costa Jr., A. E.; Mazzetto, S. E.; Fuel 2012, 97, 552.

20. BioStat, full version; AnalystSoft Inc., USA, 2009.

21. Ellman, G. L.; Courtney, K. D.; Andres Jr., V.; Featherstone, R. M.; Biochem. Pharmacol. 1961, 7, 88.

22. Rhee, I. K.; van der Meent, M.; Ingkaninan, K.; Verpoorte, R.; J. Chromatogr. 2001, 915, 217.

23. World Health Organization (WHO); https://www.who.int/ water_sanitation_health/dwq/chemicals/temephos.pdf accessed on January 23, 2019.
24. Čolović, M. B.; Krstić, D. Z.; Lazarević-Pašti, T. D.; Bondžić, A. M.; Vasić, V. M.; Curr. Neuropharmacol. 2013, 11, 315.

25. Guzman, M. G.; Gubler, D. J.; Izquierdo, A.; Martinez, E.; Halstead, S. B.; Nat. Rev. 2016, 2, 16055; Kanyaboon, P.; Saelee, T.; Suroengrit, A.; Hengphasatporn, K.; Rungrotmongkol, T.; Chavasiri Boonyasuppayakorn, S.; Sci. Rep. 2018, 8, 16643.

26. Devi, U.; Bora, D.; Asian Pac. J. Trop. Med. 2017, 10, 787.

27. Bharate, S. B.; Prins, J. M.; George, K. M.; Thompson, C. M.; J. Agric. Food Chem. 2010, 58, 8460.

28. Verheyen, J.; Stoks, R.; Environ. Pollut. 2019, 248.

29. Yu, S. J.; The Toxycology and Biochemistry of Insecticides, $6^{\text {th }}$ ed.; Taylor \& Francis: Florida, 2008.

30. Oliveira, O. V.; Cuya, T.; Ferreira, E. C.; Gonçalves, A. S.; Chem. Phys. Lett. 2018, 706, 82.

31. Horn, G.; de Koning, M. C.; van Grol, M.; Thiermann, H.; Worek, F.; Toxicol. Lett. 2018, 299, 218.

32. Oliveira, M. S. C.; Morais, S. M.; Magalhães, D. V.; Batista, W. P.; Vieira, I. G. P.; Craveiro, A. A.; Manezes, J. E. S. A.; Carvalho, A F. U.; Lima, G. P. G.; Acta Trop. 2011, 117, 165

Submitted: February 6, 2019 Published online: August 6, 2019 